\title{
MENINGKATKAN KEMAMPUAN PEMECAHAN MASALAH DENGAN PEMBELAJARAN KOOPERATIF TIPE STUDENT TEAM ACHIEVEMENT DIVISION
}

\author{
Damayanti Kusuma Wardani \\ FMIPA, Unimed Medan \\ email :damayanti_kw@yahoo.co.id \\ Wamington Rajagukguk \\ Dosen Matematika FMIPA Unimed Medan \\ email : w.rajagukguk@yahoo.co.id
}

\begin{abstract}
This study aims to improve students' problem-solving abilities with STAD cooperative learning model on the subject of integers class VII SMP Negeri 3 Galang. This type of research is a classroom action research. The subjects were students of class VII-1 SMP Negeri 3 Assemble TA2014/2015 which amounted to28 students. The object of this study is an effort to improve the ability of mathematical problem solving through cooperative learning model Student Team Achievement Division(STAD) on the subject of Integer. The research instrument used is the observation and mathematical problem solving ability test. From the results of problem solving ability test, the data obtained were 9 students (32.14\%), which reached the criteria of problemsolving abilities. After being given the treatment by applying the learning model STAD (first cycle), it is provided TKPMI .From the TKPMI data showed that as many asl6students(57.14\%) of the28students(2.74 value) that reaches criteria problem-solving abilities. This shows that in the first cycle of mathematical problem solving ability of students as a whole has not reached $85 \%$, the continued action on the second cycle. From the results TKPMII data showed that as many as 24 students $(85.71 \%)$ of the 28 students (3.15 value) that reaches criteria problem-solving abilities. This shows that the mathematical problem solving ability of students as a whole has reached $85 \%$, then the action is stopped. Based on the above results, it can be concluded that by applying STAD cooperative learning model can improve students' mathematical problem solving ability on the subject of integers in class VII SMP Negeri 3 Galang.
\end{abstract}

Keywords: STAD, improve, test, problem, solving

\section{PENDAHULUAN}

Matematika merupakan ilmu universal yang mendasari perkembangan teknologi modern, mempunyai peran penting dalam berbagai disiplin ilmu pengetahuan dan mengembangkan daya pikir manusia.Matematika merupakan pelajaran di sekolah yang dipandang penting dan dipelajari oleh setiap peserta didik mulai dari sekolah dasar hingga sekolah lanjutan tingkat atas dan bahkan juga perguruan tinggi. Oleh karena itu, matematika sangat diperlukan untuk kehidupan sehari-hari dalam menghadapi kemajuan IPTEK. Seperti yang dikemukakan oleh Cornelius (Abdurrahman, 2009:253) bahwa : "Lima alasan perlunya belajar matematika karena matematika merupakan (1) sarana berfikir yang jelas dan logis, (2) sarana untuk memecahkan masalah kehidupan sehari-hari, (3) sarana mengenal pola-pola hubungan dan generalisasi pengalaman, (4) sarana untuk mengembangkan kreativitas, dan (5) sarana untuk meningkatkan kesadaran terhadap perkembangan budaya". 
Salah satu masalah pembelajaran di sekolah adalah rendahnya pemecahan masalah siswa. Indikasinya terlihat dari hasil prestasi atau hasil belajar siswa di sekolah. Faktor-faktor yang menyebabkan ketidakmampuan siswa memecahkan masalah matematika banyak, yang paling dominan adalah cara mengajar guru. Guruguru masih mengajar dengan cara lama, dimana guru menyampaikan materi dengan metode ceramah, kemudian siswa mencatat materi dan mengerjakan soal-soal rutin. Terbiasanya siswa mengerjakan soal-soal rutin membuat siswa tidak dapat memecahkan suatu masalah apabila diberikan soal-soal yang berbentuk non rutin. Mereka tidak terbiasa untuk memecahkan suatu masalah secara bebas dan mencari solusi penyelesaiannya dengan cara mereka sendiri. Mereka hanya bisa mengerjakan soal-soal yang bentuknya sama dengan contoh soal yang diberikan guru. Apabila soalnya berbeda mereka mulai kebingungan karena mereka tidak memahami langkah-langkah dalam memecahkan suatu masalah.

Dari hasil tes kemampuan pemecahan masalah yang telah dilaksanakan di kelas VIII-1diperoleh data bahwa sebagian besar siswa hanya mampu menyelesaikan soal yang sudah ada contoh penyelesaiannya, siswa hanya mengikuti langkah-langkah yang diberikan guru pada contoh soal. Namun ketika sedikit dirubah maka siswa akan mengalami kesulitan untuk mengerjakan soal tersebut, terutama pada saat ada soal cerita, mereka akan sulit mengetahui apa yang diketahui dan ditanya pada soal. Hal ini karena pemecahan masalah siswa masih sangat rendah.

Dari hasil tes tersebut, kesulitan siswa terletak pada aspek memahami masalah, membuat model matematika, menyelesaikan masalah, membuat garis bilangan, dan memeriksa prosedur serta melakukan perhitungan.

Berbagai upaya telah dilakukan untuk mengatasi masalah ini, namun belum memperlihatkan hasil yang optimal.Oleh karena itu perlu di upayakan pembelajaran yang dapat meningkatkan kemampuan pemecahan masalah matematika terutama pada materi bilangan bulat.

Salah satu cara yang dapat meningkatkan kemampuan pemecahan masalah siswa adalah model pembelajaran kooperatif tipe Student Team Achievement Division (STAD), Menurut Robert E. Slavin (2011:143) "Model pembelajaran kooperatif melalui pendekatan struktural tipe Student Team Achievement Division (STAD), merupakan tipe pembelajaran kooperatif yang paling sederhana dan merupakan model yang paling baik untuk permulaan bagi para guru yang baru menggunakan pendekatan kooperatif.". Di samping itu model pembelajaran kooperatif tipe STAD tidak hanya unggul dalam membantu siswa memahami konsep-konsep sulit, tetapi juga sangat berguna untuk menumbuhkan kemampuan interaksi antara guru dan siswa, meningkatkan kerja sama, kreativitas, berpikir kritis serta ada kemauan membantu teman.

Berdasarkan uraian di atas, bahwa kemampuan pemecahan masalah merupakan tujuan pembelajaran matematika yang sangat penting, dan salah satu pembelajaran yang dapat meningkatkan kemampuan pemecahan masalah siswa.

Berdasarkan latar belakang yang telah diuraikan diatas maka dapat diidentifikasikan masalah sebagai berikut:

1. Rendahnya kemampuan siswa menyelesaikan soal pemecahan masalah matematika.

2. Kegiatan pembelajaran yang masih berpusat kepada guru.

3. Proses pembelajaran yang kurang mendukung siswa untuk aktif dalam menyelesaikan ide-ide/gagasannya sendiri.

4. Hasil belajar siswa masih rendah.

Adapun tujuan dari penelitian ini adalah untuk :

Meningkatkan pemecahan masalah siswa melalui penerapan model pembelajaran kooperatif

StudentTeamAchievementDivision

(STAD) pada pokok bahasan bilangan 
bulat pada kelas VII SMP Negeri 3 Galang

\section{a. Kemampuan Pemecahan Masalah Matematika}

Menurut Polya (Hudojo,2005:128) terdapat dua macam masalah di dalam matematika, yaitu : Masalah untuk menemukan, dapat teoritis atau praktis, abstrak atau konkret, termasuk tekateki.

Adapun langkah-langkah dalam menyelesaikan masalah yang dikemukakan oleh Polya (dalam Syaban,

http://miftahulsakinah.wordpress.co m) adalah sebagai berikut :

1. Memahami Masalah

Pada kegiatan ini yang dilakukan adalah merumuskan: apa yang diketahui, apa yang ditanyakan, apakah informasi cukup, kondisi (syarat) apa yang harus dipenuhi, menyatakan kembali masalah asli dalam bentuk yang lebih operasional (dapat dipecahkan).

2. Merencanakan pemecahannya

Kegiatan yang dilakukan pada langkah ini adalah mencoba mencari atau mengingat masalah yang pernah diselesaikan yang memiliki kemiripan dengan sifat yang akan dipecahkan, mencari pola atau aturan , menyusun prosedur penyelesaian.

3. Melaksanakan rencana

Kegiatan pada langkah ini adalah menjalankan prosedur yang telah dibuat pada langkah sebelumnya untuk mendapatkan penyelesaian

4. Memeriksa kembali prosedur dan hasil penyelesaian

Kegiatan pada langkah ini adalah menganalis dan mengevaluasi apakah prosedur yang diterapkan dan hasil yang diperoleh benar, apakah ada prosedur lain yang lebih efektif, apakah prosedur yang dibuat dapat digunakan untuk menyelesaikan masalah sejenis, atau apakah prosedur dapat dibuat generalisasinya.

\section{b. Belajar}

Belajar merupakan proses yang terus menerus berlangsung dalam perjalanan hidup manusia. Belajar merupakan salah satu faktor yang mempengaruhi dan berperan penting dalam pembentukan pribadi dan perilaku individu. Anthony Robbins (dalam Trianto, 2011:16) mendefenisikan "belajar sebagai proses menciptakan hubungan antara sesuatu yang sudah dipahami dan sesuatu yang baru"

\section{c. Hasil Belajar Siswa}

Hasil belajar merupakan kemampuan yang diperoleh individu setelah proses belajar berlangsung, yang dapat memberikan perubahan tingkah laku baik pengetahuan, pemahaman, sikap, dan keterampilan peserta didik sehingga menjadi lebih baik dari sebelumnya. A.J.Romiszowski (dalam Abdurrahman, 2012:26) menjelaskan bahwa : "Hasil belajar merupakan keluaran (outputs) dari suatu sistem pemrosesan masukan (inputs). Masukan dari sistem tersebut berupa macam-macam informasi sedangkan keluarannya adalah perbuatan atau kinerja (performance).

\section{d. Aktivitas Belajar}

Aktivitas belajar adalah suatu aktivitas yang sadar akan tujuan. Tujuan dalam belajar adalah terjadinya perubahan dalam individu seutuhnya. Menurut Djamarah (2002), ada beberapa aktivitas belajar sebagai berikut:

(1)Mendengarkan, (2)Memandang, (3)Meraba, Membau, dan Mencicipi / Mengecap, (4)Menulis atau mencatat, (5)Membaca, (6)Membuat ikhtisar atau ringkasan dan menggarisbawahi, (7)Mengamati tabel-tabel, diagram-diagram dan bagan-bagan, (8)Menyusun paper 
atau kertas kerja, (8)Mengingat, (9)Berpikir, dan (10)Latihan atau praktek.

Ada banyak aspek aktivitas yang telah dikelompokkan oleh Djamarah.

Sementara Sardiman (2011), menyatakan "aktivitas belajar adalah kegiatan yang bersifat fisik/jasmani maupun mental/rohani yang berkaitan dengan kegiatan belajar.

e. Model Pembelajaran Kooperatif

Menurut Slavin (Isjoni,2011:15) Pembelajaran kooperatif adalah suatu model pembelajaran dimana sistem belajar dan bekerja dalam kelompokkelompok kecil yang berjumlah 4-6 orang secara kolaboratif sehingga dapat merangsang siswa lebih bergairah dalam belajar. Sedangkan Johnson (Isjoni,2011:15) mengemukakan, kooperative learning mengandung arti bekerja sama dalam mencapai tujuan bersama. Dalam kegiatan kooperatif, siswa mencari hasil yang menguntungkan bagi seluruh anggota kelompok.Belajar kooperatif adalah pemanfaatan kelompok kecil untuk memaksimalkan belajar mereka dan belajar anggota lainnya dalam kelompok itu.

f. Pengertian Model Pembelajaran Kooperatif tipe STAD

STAD merupakan pendekatan pembelajaran kooperatif yang paling sederhana.STAD mengacu kepada belajar kelompok dimana siswa dibentuk dalam beberapa kelompok.Seperti yang dikemukakan oleh Isjoni (2011:51) bahwa StudentTeamAchievementDivision (STAD) merupakan pembelajaran kooperatif yang dikembangkan oleh Slavin, dan merupakan salah satu tipe kooperatif yang menekankan pada adanya aktivitas dan interaksi diantara siswa untuk saling memotivasi dan saling membantu dalam menguasai materi pelajaran guna mencapai prestasi yang maksimal.

g. langkah-langkah Proses

Pembelajaran Kooperatif tipe STAD

Senada dengan Nurasman, menurut Istarani (2012:20) langkah-langkah terukur dan sistematis dari model pembelajaran tipe STAD adalah sebagai berikut:

1. Membentuk kelompok yang beranggotakan \pm 4 orang secara heterogen (prestasi, jenis kelamin, suku dan lain-lain)

2. Guru menyajikan pelajaran

3. Guru memberi tugas kepada kelompok untuk dikerjakan oleh anggota-anggota kelompok

4. Guru memberikan kuis/pertanyaan kepada seluruh peserta didik , pada saat menjawab kuis tidak boleh saling membantu

5. Memberi evaluasi

6. Kesimpulan

Berdasarkankerangka konseptual yang telah diuraikan, maka yang menjadi hipotesis tindakan pada penelitian ini adalah sebagai berikut :

1. Strategi Penerapan model pembelajaran

StudentTeamAchievementDivisiond apat meningkatkan kemampuan pemecahan masalah matematika siswa pada materi bilangan bulat di kelas VII SMP Negeri 3 Galang.

2. Kemampuan pemecahan masalah siswa akan lebih meningkat dengan menerapkan model pembelajaran kooperatif tipe StudentTeamAchievementDivisionp ada pokok bahasan bilangan bulat di SMP Negeri 3 Galang.

\section{METODE PENELITIAN}

Jenis penelitian ini adalah penelitian tindakan kelas (Classroom Action Research). Penelitian yang 
dilakukan adalah penelitian kualitatif karena penelitian ini bertujuan untuk menjelaskan upaya-upaya yang dilakukan untuk meningkatkan kemampuan pemecahan masalah matematika siswa dan kendalanya dalam proses belajar.

Penelitian ini dilakukan di SMP Negeri 3 Galang, kelas VII dan pelaksanaannya pada semester ganjil, Tahun Pelajaran 2014/2015.

Subjek dalam penelitian ini adalah siswa kelas VIII-1 SMP Negeri 3 Galang Tahun Ajaran 2014/2015, yang berjumlah 28 orang.

Objek dalam penelitian ini adalah upaya meningkatkan kemampuan pemecahan masalah matematika melalui model pembelajaran kooperatif tipe StudentTeamAchievementDivision $(\mathrm{S}$

TAD)pada pokok bahasan Bilangan Bulat dikelas VIII SMP Negeri 3Galang Tahun Pelajaran 2014/2015.

\section{a. Prosedur Penelitian}

Sesuai dengan jenis penelitian ini, yaitu penelitian tindakan kelas, maka penelitian ini memiliki tahap-tahap penelitian yang berupa siklus.Mekanisme dalam penelitian ini terdiri dari dua siklus, tiap siklus dilaksanakan sesuai dengan perubahan yang ingin dicapai.Disetiap siklus diakhiri dengan diadakannya tes hasil belajar.

\section{Permasalahan}

Masalah yang diduga oleh penulis dalam penelitian ini adalah pemecahan masalah matematika siswa pada materi Bilangan Bulat

\section{Alternatif Pemecahan} (Rencana Tindakan )

Dari masalah di atas, peneliti membuat pemecahan melaksanakan pembelajaran menggunakan alternatif yaitu

kegiatan dengan model pembelajaran yang melibatkan seluruh siswa tanpa terkecuali

3. Pelaksanaan Tindakan

Melakukan kegiatan pembelajaran yang secara keseluruhan kegiatannya akan dikelompokkan dalam 2 siklus.

\section{Observasi}

Observasi dilakukan pada saat yang bersamaan pada saat pelaksanaan tindakan pembelajaran

\section{Analisis Data}

Data yang diperoleh dari tes kemampuan pemecahan masalah matematika siswa dianalisis berupa tabel setelah itu dilakukan perhitungan untuk memperoleh hasil dari tes kemampuan pemecahan masalah siswa.

\section{Refleksi}

Tahapan ini dilakukan untuk memberikan makna dan memikirkan/ merenungkan data yang diperoleh dari tindakan yang dilakukan.Hasil refleksi ini kemudian digunakan sebagai dasar untuk tahap perencanaan pada siklus selanjutnya.

\section{b. Instrumen Dan}

Teknik

\section{Pengumpulan Data}

Instrumen yang digunakan dalam mengumpulkan data pada penelitian ini adalah tes, dan observasi.

c. Teknik Analisis Data

Setelah dilakukan tes kemampuan pemecahan masalah kepada siswa,untuk mengetahui tingkat kemampuan pemecahan masalah siswa secara individual digunakan rumus:

$$
T K P M=\frac{B}{N} \times 4
$$

Keterangan: 
TKPM : Tingkat kemampuan pemecahan masalah siswa

$B$ : Jumlah skor kemampuan pemecahan masalah yang diperoleh siswa

$N$ : Jumlah skor total kemampuan pemecahan masalah Penilaian kemampuan pemecahan masalah siswa menggunakan skala 1-4 dengan kelipatan 0,33 ( Peraturan Menteri Pendidikan dan Kebudayaan RI No 81a Tahun 2013).

- Penentuan Persentase Kelas telah Mampu Memecahkan Masalah

$$
D S K=\frac{M}{N} x 100 \%
$$

Ket $: D S K=$ persentase kelas yang mampu memecahkan masalah $M=$ banyak siswa memperoleh

kategori sedang

$$
N=\text { banyak siswa seluruhnya }
$$

Dengan kriteria:

$0 \% \leq D S K<85 \%$; kelas belum

mampu memecahkan masalah

$85 \% \leq D S K \leq 100 \%$; kelas telah

mampu memecahkan masalah

\section{- Analisis Hasil Observasi}

Dari hasil observasi yang telah dilakukan peneliti, dilakukan penganalisaan dengan menggunakan rumus:

$$
P_{i}=\frac{\text { jumlah seluruh aspek yang diamati }}{\text { banyaknya aspek yang diamati }}
$$

\section{- Reduksi Data}

Proses reduksi data dilakukan

dengan menyeleksi,

menyederhanakan dan

mentransformasikan data yang telah

disajikan dalam bentuk transkrip

catatan lapangan

- Paparan Data

Data kesalahan jawaban siswa yang telah direduksi kemudian disajikan dalam bentuk paparan data kesalahan jawaban siswa.

- Verifikasi

Kegiatan verifikasi dilakukan terhadap kesalahan jawaban siswa dengan menafsirkan dan membuat kesimpulan tindakan-tindakan apa yang dilakukan untuk memperbaiki kesalahan jawaban siswa dalam menyelesaikan soal-soal bilangan bulat.

\section{- Menarik Kesimpulan}

Kesimpulan yang diambil merupakan dasar bagi pelaksanaan siklus berikutnya dan perlu tindakan siklus dilajutkan atas permasalahan yang diduga.

\section{HASIL DAN PEMBAHASAN Permasalahan}

Berdasarkan hasil wawancara dengan guru matematika kelas VII SMP Negeri 3 Galang, diperoleh bahwa kemampuan pemecahan masalah matematika siswa rendah.Soal cerita menjadi masalah dalam pembelajaran matematika di kelas yang diajar guru tersebut.Sebelum melaksanakan tindakan, peneliti memberikan tes awal kepada siswa. Tes awal ini terdiri dari dua soal pemecahan masalah dengan topik bilangan bulat yang telah diajarkan. Hasil perolehan pada tes kemampuan pemecahan masalah awal dideskripsikan tingkat kemampuan siswa memecahkan masalah sebagai berikut:dengan 2 butir soal terdapat $50 \%$ siswa yang sudah mampu memahami masalah, hanya $17,85 \%$ yang sudah mampu merencanakan pemecahan masalah, 35,7\%yang sudah mampu melaksanakan pemecahan masalah, dan hanya $16,08 \%$ yang sudah mampu memeriksa kembali.

Secara keseluruhan, kemampuan siswa dalam memecahkan masalah diperoleh, tidak ada siswa dari 28 siswa yang 
memiliki predikat A, tidak ada siswa yang memiliki predikat A, tidak ada siswa yang memiliki predikat $\mathrm{B}+, 2$ siswa atau $7,14 \%$ yang memiliki predikat $\mathrm{B}, 7$ siswa atau $25 \%$ yang memiliki predikat $\mathrm{B}-$, tidak ada siswa yang memiliki predikat $\mathrm{C}+$, tidak ada siswa yang memiliki predikat C, 4 siswa atau $1428 \%$ yang memiliki predikat C-, 1 siswa atau 3,57 yang memiliki predikat $\mathrm{D}+, 14$ siswa atau $50 \%$ yang memiliki predikat D. Ratarata skor kemampuan pemecahan masalah matematika I adalah 1,39.

Berdasarkan hasil observasi oleh observator terhadap kegiatan pembelajaran pada siklus I, diperoleh nilai rata-rata untuk peneliti yang bertindak sebagai guru dalam mengelola pembelajaran pada pertemuan I sebesar 2,8 dan pertemuan II sebesar 2,9. Berdasarkan hasil observasi secara keseluruhan, kemampuan peneliti dalam melaksanakan pembelajaran pada siklus I adalah 2,85 dengan kategori baik. Dari hasil yang diperoleh, pengelolaan pembelajaran semakin meningkat dari pertemuan I ke pertemuan II, ini dapat dilihat dari nilai yang diberikan observer semakin meningkat. Walaupun sudah terjadi peningkatan, namun guru masih kurang maksimal dalam mengarahkan siswa untuk aktif berinteraksi dalam diskusi dan siswa masih dalam tahap penyesuaian dengan strategi pembelajaran yang baru sehingga suasana kelas agak ribut dalam proses pembelajaran.

- Hasil Tes Kemampuan Pemecahan Masalah Matematika I
Berdasarkan hasil jawaban siswa yang diberikan pada tes kemampuan pemecahan masalah I dideskripsikan tingkat kemampuan siswa memecahkan masalah sebagai berikut:

Dengan 4 butir soal terdapat $70,53 \%$ siswa yang sudah mampu memahami masalah, $51,78 \%$ yang sudah mampu merencanakan pemecahan masalah, 68,92\%yang sudah mampu melaksanakan pemecahan masalah dan $60,71 \%$ yang sudah mampu memeriksa kembali.

Secara keseluruhan diperoleh bahwa kemampuan siswa dalam menyelesaikan soal meningkat dari tes awal. Hal ini dapat dilihat dari peningkatan rata-rata dan ketuntasan klasikal antara tes awal dan tes kemampuan pemecahan masalah matematika I. 1 dari 28 siswa atau $3,57 \%$ yang memiliki predikat A, 4 siswa atau $7,89 \%$ yang memiliki predikat A-, 3 siswa atau $7,89 \%$ yang memiliki predikat $\mathrm{B}+, 1$ siswa atau $28,94 \%$ yang memiliki predikat B, 7 siswa atau 10,52\% yang memiliki predikat B-, 5 siswa atau $14,29 \%$ yang memiliki predikat $\mathrm{C}+$, 5 siswa atau $17,85 \%$ yang memiliki predikat C, 2 siswa atau $15,78 \%$ yang memiliki predikat $\mathrm{C}$-, tidak ada siswa yang memiliki predikat $\mathrm{D}+$, tidak ada siswa yang memiliki predikat D. Rata-rata skor kemampuanpemecahan masalah matematika I adalah 2,74.

Berdasarkan hasil observasi yang dilakukan oleh guru matematika SMP Negeri 3 Galang pada siklus I, nilai kemampuan guru dalam melaksanakan pembelajaran pada pertemuan I adalah 2.8 (kategori baik); pada pertemuan II, 2.9 (kategori baik). Rata-rata keduapertemuan tersebut adalah 2,85 (kategori baik). 
Dari hasil tes kemampuan pemecahan masalah I yang diperoleh pada siklus I, dapat dipaparkan bahwa dari 28 orang siswa terdapat 16 orang siswa atau $57,13 \%$ mencapai ketuntasan belajar dan terdapat 12 orang siswa atau $42,37 \%$ belum mencapai kriteria ketuntasan belajar. Dengan demikian dapat disimpulkan kelas tersebut belum tuntas secara klasikal yaitu belum terdapat $\geq 80 \%$ siswa yang mencapai nilai $\geq 2,66$. Namun, dalam pembelajaran tidak seluruh siswa aktif, dan siswa juga belum mampu secara maksimal mengikuti pelajaran dengan strategi ini.

Berdasarkan hasil observasi terhadap guru dan siswa selama pembelajaran dan data dari tes kemampuan pemecahan masalah I akan diuraikan keberhasilan dan kegagalan atau kelemahan dalam pelaksanaan tindakan pada siklus I sehingga lanjut ke siklus II.

Secara keseluruhan keterampilan siswa dalam memecahkan masalah, terdapat predikat A, 11 dari 28 siswa atau 39,28\% yang memiliki predikat A-, 2 siswa atau $7,14 \%$ yang memiliki predikat $\mathrm{B}+, 8$ siswa atau $28,5 \%$ yang memiliki predikat $\mathrm{B}, 3$ siswa atau $10,71 \%$ yang memiliki predikat B, 1 siswa atau $3,57 \%$ yang memiliki predikat $\mathrm{C}+, 3$ siswa atau $10,71 \%$ yang memiliki predikat $\mathrm{C}$, tidak ada siswa yang memiliki predikat C-, tidak ada siswa yang memiliki predikat D+, tidak ada siswa yang memiliki predikat D. Rata-rata skor kemampuanpemecahan masalah matematika I adalah 3,15.

Berdasarkan hasil observasi diperoleh kesimpulan bahwa kemampuan guru dalam melakukan pembelajaran dalam menerapkan model pembelajaran STAD masuk dalam kategori baik sekali.

Setelah dilaksanakan tindakan pada siklus II dengan menerapkan model pembelajaran STAD, diperoleh bahwa kemampuan pemecahan masalah matematika siswa mengalami peningkatan dari tes kemampuan pemecahan masalah I. Hal ini dapat dilihat dari peningkatan rata-rata kelas yakni dari hasil tes kemampuan pemecahan masalah I sebesar 2,74 menjadi 3,15 pada siklus II. Demikian pula tingkat ketuntasan belajar secara klasikal meningkat, yaitu pada tes awal sebesar $57,13 \%$ menjadi $85,7 \%$ pada siklus II.

Dengan demikian berdasarkan hasil tes kemampuan pemecahan masalah II pada siklus II, diperoleh bahwa skor rata-rata kelas mencapai 3,15 dengan jumlah siswa yang memperoleh predikat B- ke atas tingkat kemampuan belajar secara klasikal mencapai $85,7 \%$. Hasil tersebut sudah mencapai tingkat ketuntasan belajar yang telah ditetapkan dan tingkat kemampuan siswa memecahkan masalah sudah memuaskan. Karena 85,7\% siswa memperoleh kategori minimal sedang dalam pemecahan masalah (tingkat ketuntasan telah tercapai), dan tingkat kemampuan guru mengelola pembelajaran dalam kategori baik, maka guru tidak melanjutkan ke siklus III.

\section{Pembahasan dan Hasil Penelitian}

Dengan menerapkan model pembelajaran STAD dalam pembelajaran ini, dapat meningkatkan kemampuan pemecahan masalah matematika siswa khususnya pada pokok bahasan bilangan bulat. Hal ini didasari pada pelaksanaan tes kemampuan pemecahan masalah yang dilaksanakan di kelas VII-1.

Sebelum penelitian dilakukan, siswa diberikan tes diagnostik sehingga diperoleh kemampuan siswa memahami masalah 50\%, kemampuan siswa merencanakan pemecahan masalah 17,85\%, kemampuan siswa melaksanakan pemecahan masalah $35,7 \%$, kemampuan siswa dalam menarik kesimpulan adalah $16,08 \%$ dan dari tes diagnostik diperoleh skor rata-rata siswa 1,39. Hasil ini menunjukkan bahwa tingkat kemampuan siswa memecahkan masalah masih rendah. Adapun kesulitan siswa dalam mengerjakan soal-soal materi bilangan bulat, yaitu:siswatidak mampu menafsirkan soal sehingga tidak bisa menentukan apa yang diketahui dan yang ditanyakan, siswa sulit dalam merencanakan penyelesaian masalah karena tidak mengetahui konsep bilangan bulat, siswa kurang teliti dalam melakukan operasi perhitungan. Salah satu upaya yang dilakukan untuk mengatasi dan 
meningkatkannya adalah melalui pembelajaran dengan model pembelajaran STAD.

Berdasarkan masalah yang ditemukan pada tes diagnostik maka diperlukan perbaikan dengan melanjutkan pada siklus I untuk meningkatkan kemampuan pemecahan masalah matematika siswa.Setelah diberikan tindakan pada siklus I melalui pembelajaran dengan model pembelajaran STAD diperoleh kemampuan siswa memahami masalah 70,53\%,kemampuan siswa merencanakan pemecahan masalah $51,78 \%$, kemampuan melaksanakan pemecahan masalah $68,92 \%$, kemampuan siswa dalam menarik kesimpulan $60,71 \%$. Diperoleh skor rata-rata siswa 2,74 dengan jumlah siswa yang mencapai kategori sedang ke atas.

Kemudian setelah memberikan tindakan pada siklus II melalui pembelajaran dengan model pembelajaran STAD dengan lebih menekankan dan menjelaskan penerapan langkah-langkah polya kepada siswa serta dengan penggunaan alat peraga, diperoleh kemampuan siswa memahami masalah 83,92 \%,kemampuan siswa merencanakan pemecahan masalah $62,5 \%$,kemampuan siswa melaksanakan pemecahan masalah $65,17 \%$, kemampuan siswa dalam memeriksa kembali hasil penyelesaian $70,59 \%$. Diperoleh nilai ratarata siswa 3,156dengan jumlah siswa yang memperoleh nilai 65 ke atas meningkat sebanyak 24 orang $(85,7 \%)$ yang mencapai kategori sedang ke atas.

Pada proses pembelajaran materi yang dibahas siswa pada siklus I tidak terlalu rumit, tapi mereka belum terbiasa melakukan STAD akibatnya butuh waktu yang lama saat mereka melakukan penyelidikan. Pada diskusi kelas mereka sangat aktif, banyak pertanyaan dan saran yang muncul. Tapi yang menjawab pertanyaan didominasi oleh ketua kelompok, tidak didiskusikan dulu. Jadi walau suasana diskusi kelas berjalan lancar tapi dalam menjawab pertanyaan tidak merata jadi kelihatan kurang sekali kebersamaan mereka saat presentasi, ini dikarenakan anggota yang lain mungkin masih gugup karena belum terbiasa berbicara di depan kelas jadi mereka kurang percaya diri. Pada Siklus II siswa sudah lebih aktif dibanding siklus I dan mereka sudah bisa bekerja lebih cepat, tidak ada anggota kelompok yang pasif, mereka mulai ada yang berani bertanya kepada guru ketika mereka mengalami kesulitan bahkan kelihatan sekali semua kelompok ingin tampil mempresentasikannya. Pada saat diskusi kelas pertanyaan atau saran yang muncul tidak sebanyak pada siklus I, karena mereka sudah mulai mengenal prosedur pengerjaannya. Kelompok yang tampil sudah kelihatan kebersamaannya, pertanyaanpertanyaan yang muncul mereka jawab secara bergantian. Guru banyak memberi bantuan pada siswa dengan cara menggali informasi dari siswa. Akhirnya tiap-tiap kelompok bisa menyelesaikan penyelidikannya, dan hasilnya pun memuaskan.

Penelitian menunjukkan bahwa penyampaian materi pelajaran pada materi bilangan bulat dapat diupayakan berhasil dengan menggunakan model pembelajaran $S T A D$. Dengan demikian pembelajaran dengan model $S T A D$ mempunyai peranan penting sebagai salah satu upaya untuk meningkatkan kemampuan pemecahan masalah matematika siswa. Sebelum pemberian tindakan, peneliti memberikan tes diagnostik untuk melihat tingkat kemampuan pemecahan masalah matematika. Dari hasil tes diperoleh bahwa kemampuan pemecahan masalah matematika masih rendah dan siswa mengalami kesulitan terhadap kemampuan dalam memecahkan masalah dari materi bilangan bulat, dengan melaluipembelajaran menerapkan model STAD, kemampuan pemecahan masalah matematika siswa tersebut dapat ditingkatkan.

\section{KESIMPULAN}

Berdasarkan hasil penelitian dan pembahasan yang disajikan pada BAB IV maka dapat diambil kesimpulan sebagai berikut :Berdasarkan hasil penelitian maka peneliti mengambil kesimpulan bahwa pembelajaran dengan menggunakan model pembelajaran 
kooperatif

tipe

StudentTeamAchievementDivision (STAD) dapat meningkatkan kemampuanpemecahan masalah siswa di kelas VII-1 SMP Negeri 3 Galang. Hal ini terlihat dari adanya peningkatan banyaknya siswa yang memiliki kemampuan pemecahan masalah minimal sedang dari siklus I ke siklus II dan pada siklus II siswa sudah memiliki kemampuanpemecahan masalah kriteria baik. Dengan model pembelajaran StudentTeamAchievementDivision (STAD), kemampuan pemecahan masalah matematika siswa pada materi bilangan bulat kelas VII SMP Negeri 3 Galang meningkat.Hal ini dapat dilihat dari banyaknya siswa yang mencapai ketuntasan padasiklus I setelah dilakukan pembelajaran dengan model STAD, banyaknya siswa yang mencapai ketuntasan belajar adalah 16 dari 28 orang $(57,14 \%)$ dengan rata-rata kelas 2,74. Hasil analisis data pada akhir siklus II dengan memaksimalkan model STAD beserta perbaikan dari siklus I, banyaknya siswa yang mencapai ketuntasan belajar adalah 24 dari 28 orang $(85,7 \%)$ dan rata-rata kelas 3,15 . Berdasarkan kriteria ketuntasan belajar klasikal maka pembelajaran ini telah mencapai target ketuntasan belajar klasikal.

\section{REFERENSI}

Abdurrahman, Mulyono, (2009), Pendidikan Bagi Anak Berkesulitan Belajar, Rineka Cipta, Jakarta.

Al-Khowarizmi, (2014), http://lela-alkhowarizmi.blogspot.com. (diakses Maret 2014)

Amustofa, (2014),

http://amustofa70.wordpress.com.

(diakses Maret 2014)

Arikunto, S. (2010), Prosedur Penelitian Rineka Cipta, Jakarta.
Aunurrahman, (2012), Belajar dan Pembelajaran, Alfabeta, Bandung

Davidson,

,http://mahirbelajar.wordpress.com/2 013/04/09/model-pembelajarankooperatif-tipe-stad/. (diakses April 2014)

Depdikbud, (2008), Matematika Konsep dan Aplikasinya, Pusat Perbukuan Departemen Pendidikan Nasional, Jakarta

Djamarah, S., (2011), Psikologi Belajar, Penerbit Rineka Cipta, Jakarta.

Dodson dan Hollander, (2014) http://amustofa70.wordpress.com. (diakses Maret 2014)

Fakultas Matematika dan Ilmu Pengetahuan Alam Universitas Negeri Medan, (2010), Buku Pedoman, Fmipa Unimed

Fakultas Matematika dan Ilmu Pengetahuan Alam Universitas Negeri Medan, (2012), Buku Pedoman Penulisan Skripsi dan Proposal Penelitian Kependidikan, Fmipa Unimed

Hamdani, (2011), Strategi Belajar Mengajar, Pustaka Setia, Bandung

Hudojo, Herman, (2005), Pengembangan Kurikulum dan Pembelajaran Matematika, IKIP Malang, Malang

Isjoni, (2011), Cooperative Learning (Efektifitas Pembelajaran Kelompok), Alfabeta, Bandung

Istarani, (2012), 58 Model Pembelajaran Inovatif, Media Persada, Medan

Polya, (2014), http://miftahulsakinah.wordpress.com (diakses April 2014 
Robert,

(2014),

http://robertmath4edu.wordpress.com . (diakses Maret 2014)

Sani, R., (2013), Inovasi Pembelajaran, Penerbit Bumi Aksara, Jakarta.

Sardiman, (2011), Interaksi dan Motivasi Belajar Mengajar,Penerbit Wali Pers, Jakarta.

Slameto,(2010), Belajar dan Faktor-faktor yang Mempengaruhinya, Rineka Cipta, Jakarta.

Slavin,

http://mahirbelajar.wordpress.com/20 13/04/09/model-pembelajaran-

kooperatif-tipe-stad/. (diakses tanggal 21 Maret 2014)

Slavin E. Robert, (2011), Cooperative Learning (Teori, Riset dan Praktik), Nusa Media, Bandung

Syaban, (2014),

http://miftahulsakinah.wordpress.com. (diakses Maret 2014)

Tapan, Imal ,http://tulisansingkatimal.blogspot.com. (diakses April 2014) 